\title{
Microscopic polyangiitis after alemtuzumab treatment in relapsing-remitting MS
}

Eva-Maria Sauer, MD, Stefan Schliep, MD, Bernhard Manger, MD, De-Hyung Lee, MD, and Ralf A. Linker, MD

Neurol Neuroimmunol Neuroinflamm 2018;5:e488. doi:10.1212/NXI.0000000000000488

Alemtuzumab is a highly effective therapy for relapsing-remitting MS (RRMS) with secondary autoimmunity as a main adverse event. Here, we present a case of microscopic polyangiitis (MPA) in a patient with RRMS secondary to alemtuzumab therapy.

\section{Case report}

A 47-year-old Caucasian woman was diagnosed with RRMS at the age of 35 years and treated with glatiramer acetate, teriflunomide, and natalizumab. After positive anti-JCV antibody status and stopping natalizumab, 2 disabling relapses occurred. She was switched to alemtuzumab and received 2 cycles without side effects and a stable disease course. Seventeen months after the last alemtuzumab infusion, she developed an erythematous, purpura-like exanthema of the lower legs and the general condition deteriorated. Laboratory testing showed thrombocytosis, mild anemia, leukocytosis with relative lymphopenia, and mildly elevated CRP levels. Skin biopsy of the erythema together with immunohistochemistry revealed infiltration with neutrophils, lymphocytes, and eosinophils around the small blood vessels in the dermis, multifocal red blood cells, and fragmented neutrophilic nuclei, consistent with mild nongranulomatous leukocytoclastic vasculitis (figure, A-C). No vessel necrosis was observed. Further laboratory studies indicated elevated perinuclear antineutrophil cytoplasmic antibody (pANCA) levels, negative anti-GBM antibodies, and normal antistreptolysin $\mathrm{O}$ titer, eosinophils, rheumatoid factor, and thyroid function. $\mathrm{CD} 4^{+} \mathrm{T}$ cells were relatively reduced, whereas levels of $\mathrm{CD} 19+/ \mathrm{CD} 20+\mathrm{B}$ cells were elevated. There was no clinical, laboratory, or imaging evidence of a pulmonary-renal syndrome. Approximately 5 years after diagnosis of RRMS, pANCA values were still normal. MPA was diagnosed based on the presence of small-vessel vasculitis and myeloperoxidase (MPO)-ANCA without proteinase-3-ANCA. Methylprednisolone was administered IV followed by a gradual oral taper. Skin and laboratory changes relieved quickly, and pANCA levels decreased. After recovery of lymphocytes, B-cell depletion with rituximab may serve as a treatment option for both RRMS and MPA. ${ }^{1}$

\section{Discussion}

MPA is a necrotizing small-vessel vasculitis with common focal necrotizing, pauci-immune glomerulonephritis, pulmonary capillaritis, and purpura. ${ }^{1,2}$ In our patient, diagnosis of MPA was confirmed by purpura-like exanthema in the context of leukocytoclastic vasculitis and the characteristic detection of MPO-ANCA in the absence of thrombocytopenia. The pathogenesis of MPA likely comprises an interplay between neutrophils, lymphocytes, endothelium, cytokine-mediated changes, the alternative pathway of the complement system, and MPOANCA. ${ }^{2}$ For maintenance immunosuppression, rituximab, methotrexate, mycophenolate mofetil, or azathioprine is recommended. ${ }^{1}$
Correspondence

Dr. Lee

de-hyung.lee@uk-erlangen.de

From the Department of Neurology (E.M.S., D.H.L., and R.A.L.), Department of Dermatology (S.S.), and Department of Internal Medicine-Rheumatology and Immunology (B.M.), Friedrich Alexander University of Erlangen-Nuremberg, Erlangen, Germany.

Funding information and disclosures are provided at the end of the article. Full disclosure form information provided by the authors is available with the full text of this article at Neurology.org/NN.

The Article Processing Charge was funded by the University of Erlangen.

This is an open access article distributed under the terms of the Creative Commons Attribution-NonCommercial-NoDerivatives License 4.0 (CC BY-NC-ND), which permits downloading and sharing the work provided it is properly cited. The work cannot be changed in any way or used commercially without permission from the journal. 

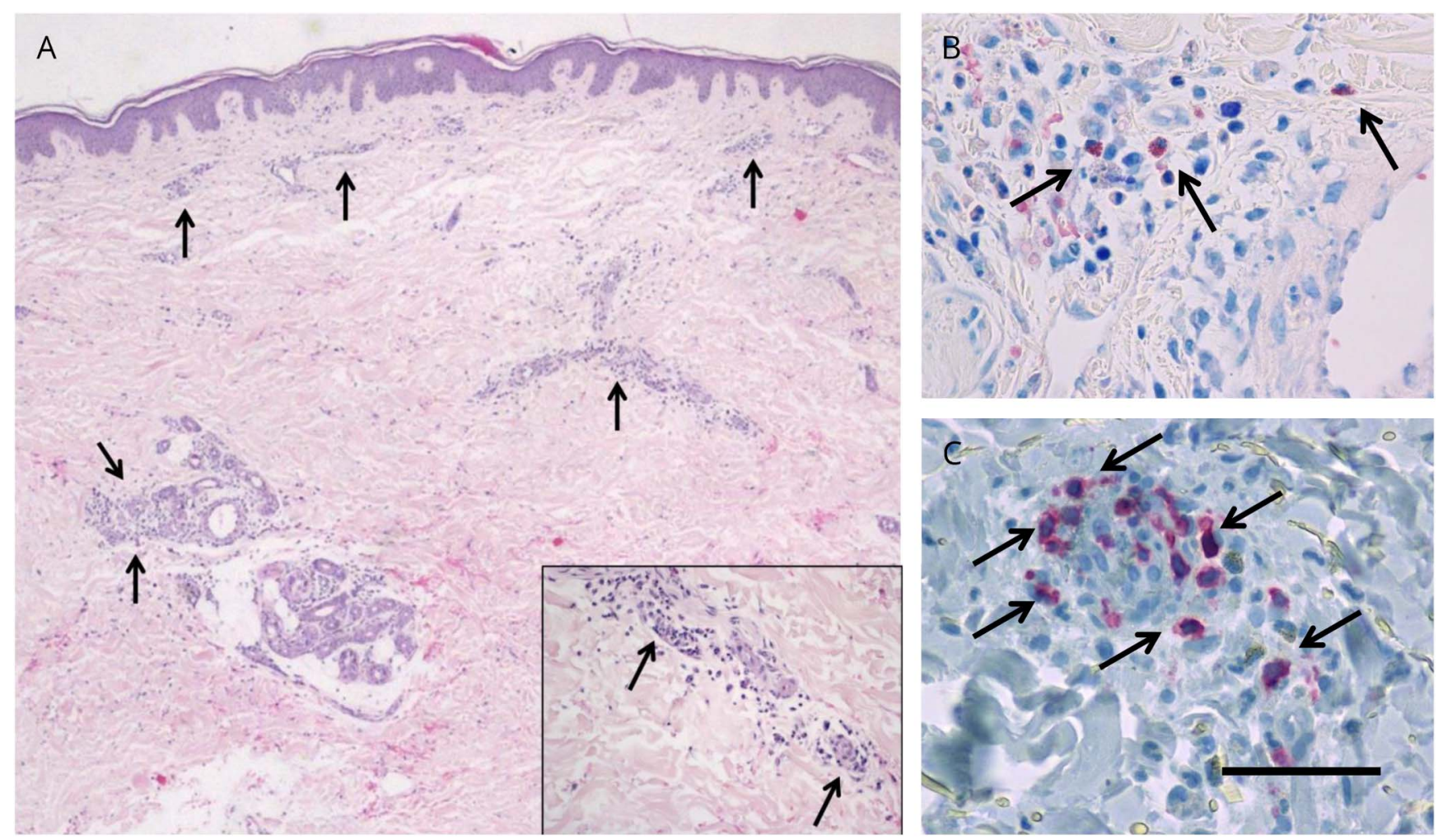

HE staining (A), Giemsa staining (B), and CD3 (C). Scale bar is depicted only in C for clarity and represents the following length: $100 \mu \mathrm{m}$ (A), $50 \mu \mathrm{m}$ (B), and $25 \mu \mathrm{m}$ (C). Arrows depict focal lymphocytes (A), and inset shows dermal infiltrate of neutrophils involving the small vessels, nuclear dust, and extravasated erythrocytes. Arrows indicate perivascular eosinophils (B) and CD3-positive lymphocytes (C).

In our case, an association between alemtuzumab treatment and MPA may be assumed, although a causal relationship cannot be confirmed. Alemtuzumab, a humanized monoclonal antibody against the surface glycoprotein CD52 temporarily depletes $\mathrm{B}$ and $\mathrm{T}$ cells and induces prolonged T-cell lymphopenia. ${ }^{3}$ It is associated with secondary B cellmediated autoimmunity mostly affecting the thyroid, less frequently immune thrombocytopenia or glomerular nephropathies. $^{3}$ Uncommon complications such as antiglomerular basement membrane disease ${ }^{4}$ or leukocytoclastic vasculitis $^{5}$ were also reported. These antibody-mediated autoimmune diseases may stem from an altered immune repertoire with early and predominant recovery of $B$ cells. The occurrence of MPA in our patient fits well with the time frame in which B-cell reconstitution occurs following alemtuzumab. ${ }^{3}$ The overshooting B-cell repopulation including potentially autoreactive $B$ cells emerging in the relative absence of $\mathrm{T}$-cell regulation may explain the resulting secondary autoimmunity in our case. ${ }^{3}$ Since B-lymphocytes are essential in the pathogenesis of $\mathrm{MPA}^{2}$ and RRMS, B-cell depletion would be a promising strategy to control B-cell hyperproliferation.

MPA should be considered in the differential diagnosis of purpura-like efflorescence after alemtuzumab therapy. Early identification and immediate treatment are vital to resolve symptoms, prevent pulmonary-renal damage, and minimize mortality.

\section{Author contributions}

E.M. Sauer: acquisition of data and analysis and interpretation. S. Schliep: acquisition of data and critical revision of the manuscript for important intellectual content. B. Manger: critical revision of the manuscript for important intellectual content. D.H. Lee: analysis and interpretation and critical revision of the manuscript for important intellectual content. R.A. Linker: critical revision of the manuscript for important intellectual content.

\section{Study funding}

No targeted funding reported.

\section{Disclosure}

E.M. Sauer reports no disclosures. S. Schliep received speaker honoraria from Martha-Maria Hospital, Nurnberg, and University of Erlangen-Nurnberg. B. Manger served on the data safety monitoring board of Archigen Biotech Ltd; received travel funding and/or speaker honoraria from AbbVie, AstraZeneca, Berlin-Chemie, BMS, Celgene, Chugai, Genzyme, GSK, Janssen, Lilly, MSD, Novartis, Pfizer, Roche, Savient, SOBI, and UCB; and is a section editor of Current Rheumatology Reports. D.H Lee reports no disclosures; R.A. 
Linker served on the scientific advisory boards of Biogen, Genzyme, Merck, Novartis, Roche, and Teva; received travel funding and/or speaker honoraria from Biogen, Genzyme, Merck, Novartis, Roche, and Teva; consulted for Biogen, Novartis, and Roche; and received research support from Biogen and Novartis. Full disclosure form information provided by the authors is available with the full text of this article at Neurology.org/NN.

Received March 13, 2018. Accepted in final form May 16, 2018.

\section{References}

1. Yates M, Watts RA, Bajema IM, et al. EULAR/ERA-EDTA recommendations for the management of ANCA-associated vasculitis. Ann Rheum Dis 2016;75:1583-1594.

2. Kallenberg CG. Pathogenesis and treatment of ANCA-associated vasculitides. Clin Exp Rheumatol 2015;33:S11-S14.

3. Guarnera C, Bramanti P, Mazzon E. Alemtuzumab: a review of efficacy and risks in the treatment of relapsing remitting multiple sclerosis. Ther Clin Risk Manag 2017;13: 871-879.

4. Meyer D, Coles A, Oyuela P, Purvis A, Margolin DH. Case report of anti-glomerular basement membrane disease following alemtuzumab treatment of relapsing-remitting multiple sclerosis. Mult Scler Relat Disord 2013;2:60-63.

5. Garten L, Edwards K, Lezcano C, Spiro J, Siuta J, Belcher S. Case report: leukocytoclastic vasculitis in an MS patient following alemtuzumab treatment. Neurology 2017;88(16 suppl): P5.403. 


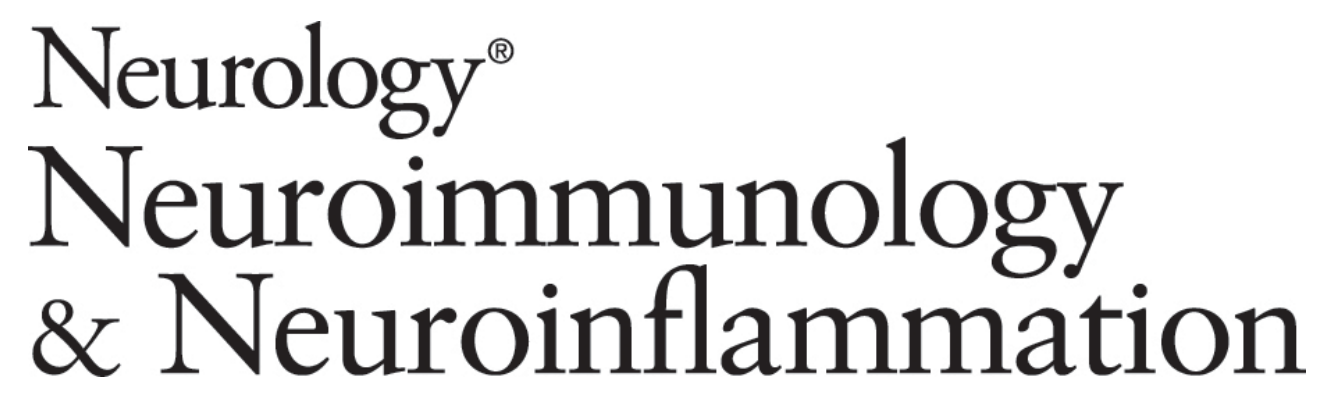

Microscopic polyangiitis after alemtuzumab treatment in relapsing-remitting MS Eva-Maria Sauer, Stefan Schliep, Bernhard Manger, et al.

Neurol Neuroimmunol Neuroinflamm 2018;5;

DOI 10.1212/NXI.0000000000000488

This information is current as of August 10, 2018

Neurol Neuroimmunol Neuroinflamm is an official journal of the American Academy of Neurology.

Published since April 2014, it is an open-access, online-only, continuous publication journal. Copyright

Copyright $\odot 2018$ The Author(s). Published by Wolters Kluwer Health, Inc. on behalf of the American

Academy of Neurology.. All rights reserved. Online ISSN: 2332-7812.

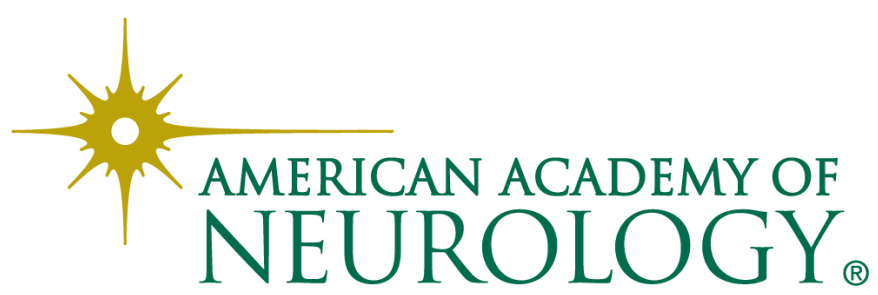




\section{Updated Information \& Services}

References

Citations

Subspecialty Collections

Permissions \& Licensing

Reprints including high resolution figures, can be found at: http://nn.neurology.org/content/5/5/e488.full.html

This article cites 5 articles, 1 of which you can access for free at: http://nn.neurology.org/content/5/5/e488.full.html\#\#ref-list-1

This article has been cited by 1 HighWire-hosted articles: http://nn.neurology.org/content/5/5/e488.full.html\#\#otherarticles

This article, along with others on similar topics, appears in the following collection(s):

All Immunology

http://nn.neurology.org//cgi/collection/all_immunology

Autoimmune diseases

http://nn.neurology.org//cgi/collection/autoimmune_diseases

Multiple sclerosis

http://nn.neurology.org//cgi/collection/multiple_sclerosis

Vasculitis

http://nn.neurology.org//cgi/collection/vasculitis

Information about reproducing this article in parts (figures,tables) or in its entirety can be found online at:

http://nn.neurology.org/misc/about.xhtml\#permissions

Information about ordering reprints can be found online:

http://nn.neurology.org/misc/addir.xhtml\#reprintsus

Neurol Neuroimmunol Neuroinflamm is an official journal of the American Academy of Neurology.

Published since April 2014, it is an open-access, online-only, continuous publication journal. Copyright

Copyright $\odot 2018$ The Author(s). Published by Wolters Kluwer Health, Inc. on behalf of the American

Academy of Neurology.. All rights reserved. Online ISSN: 2332-7812.

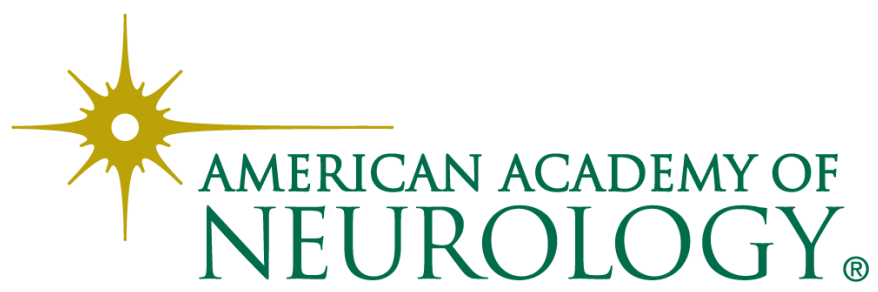

